\title{
Effect of Phosphorus, Zinc and Iron on Yield and Quality of Wheat in Western Rajasthan, India
}

\author{
Ram Chandar Jat, Yogesh Sharma, R.K. Jakhar* and R.K. Sharma
}

Department of Soil Science and Agricultural Chemistry, College of Agriculture, Swami

Keshwanad Rajasthan Agriculture University, Bikaner, India

*Corresponding author

\section{A B S T R A C T}

\section{Keywords}

Phosphorus, Zinc,

Iron, Yield,

Chlorophyll

content, Protein

content, Wheat

\section{Article Info}

Accepted:

16 February 2018

Available Online:

10 March 2018

A field experiment was carried out during two consecutive rabi seasons of 2009-10 and 2010-11 at the Agronomy farm, College of Agriculture, Swami Keshwanand Rajasthan Agricultural University, Bikaner to find out the effect of phosphorus, zinc and iron on yield and quality of wheat (Triticum aestivum L.) in Loamy sand soils of Western Rajasthan with ten treatments comprising 4 levels of phosphorus $\left(0,20,40\right.$ and $\left.60 \mathrm{~kg} \mathrm{ha}^{-1}\right)$ and zinc $\left(0,3\right.$ and $\left.6 \mathrm{~kg} \mathrm{ha}^{-1}\right)$ in main plots and 3 levels of iron $\left(0,3\right.$ and $\left.6 \mathrm{~kg} \mathrm{ha}^{-1}\right)$ in splitplot design with three replications. Application of phosphorus up to $40 \mathrm{~kg} \mathrm{P}_{2} \mathrm{O}_{5} \mathrm{ha}^{-1}$ significant]y increased the grain, straw and biological yields beyond which it increased non-significantly and registered a mean increase of 26.2, 30.6 and 28.8 per cent, respectively over control. Application of phosphorus @ $40 \mathrm{~kg} \mathrm{P}_{2} \mathrm{O}_{5} \mathrm{ha}^{-1}, 3 \mathrm{~kg} \mathrm{Zn} \mathrm{ha}{ }^{-1}$ and of $6 \mathrm{~kg} \mathrm{Fe} \mathrm{ha-1} \mathrm{significantly} \mathrm{increased} \mathrm{the} \mathrm{chlorophyll} \mathrm{content} \mathrm{of} \mathrm{wheat} \mathrm{at} \mathrm{flowering} \mathrm{stage}$ and protein content of grains in wheat during both the years of investigations and in pooled analysis. Whereas, Application of higher doses of phosphorus, zinc and iron did not had significant effect on total sugar content of grain and crude fibre content.

\section{Introduction}

Wheat [Triticum aestivum (L.)] is the second most important food grain crop in India ranking next to rice (Oryza sativa L.) contributing about $35 \%$ of the food grain production in India. India occupies second position next to China in the World with regard to area 30.96 million hectares and production 88.94 million tones with average productivity of $28.72 \mathrm{q} \mathrm{ha}^{-1}$ of wheat
(Anonymous, 2014-15). In India, main wheat growing states are UP, Punjab, Haryana, M.P., Rajasthan and Bihar. In Rajasthan, wheat has an area of 2.94 million hectares with the production of 9.86 million tonnes. The average productivity of wheat in the state is $33.65 \mathrm{q} \mathrm{ha}^{-1}$ (Anonymous, 2014-15). This clearly indicates that in spite of considerable improvement in genetic potential of the crop, productivity is still very poor in the country as well as in the state of Rajasthan. The high 
productivity of wheat can only be achieved by the adoption of suitable variety and improved agronomic practices with balanced and judicious use of chemical fertilizers in an integrated way.

Among the essential nutrients, phosphorus occupies a key place in intensive agriculture and is considered as a backbone of any fertilizer management programme. Application of phosphorus not only increases the crop yield but also improves crop quality and imparts resistance against diseases. It is involved in wide range of plant processes as permitting cell division, development of sound root system and ensuring timely and uniform ripening of crop. It participates in metabolic activities as a constituent of nucleoprotein and nucleotides and also plays a key role in the formation of energy rich bond phosphate like Adenosine diphosphate and Adenosine triphosphate. It plays a vital role in virtually every plant process like photosynthesis, energy storage and transfer, stimulating root development and growth, giving plant rapid and vigorous start leading to better tillering in wheat, encouraging earlier maturity and seed formation. Therefore, sufficient quantity of soluble form of phosphorus fertilizers is applied to achieve maximum plant productivity. However, the applied soluble forms of phosphatic fertilizers rapidly become unavailable to plants by conversion into inorganic $\mathrm{P}$ fractions that are fixed by chemical adsorption and precipitation. Similarly, organic P fractions are immobilized in soil organic matter (Sanyal and De Dutta, 1991).

Micronutrients were first recognized as a limiting factor in crop production in United States in Florida during the 1920's. Micronutrients play a vital role in enhancing crop productivity. Intensification of agriculture with high yielding varieties, continuous use of high analysis fertilizers, restricted supply of organic manures and negligible crop residue return to soil led to micronutrient deficiency. The overall deficiency of micronutrient in Indian soil was found to be 47 per cent for $\mathrm{Zn}, 2$ per cent for $\mathrm{Cu}, 13$ per cent for $\mathrm{Fe}$ and 4 per cent for $\mathrm{Mn}$ (Sakal and Singh, 2001). The present investigation was carried out to evaluate and describe the fertilizer phosphorus, zinc and iron application on growth attributes and yield attributes of wheat in Loamy sand soils of Western Rajasthan.

\section{Materials and Methods}

The experiment was conducted at the Agronomy farm, College of Agriculture, Swami Keshwanand Rajasthan Agricultural University, Bikaner during rabi seasons of 2009-10 and 2010-11. The experimental site is located at $28.01^{\circ} \mathrm{N}$ latitude and $73.22^{\circ} \mathrm{E}$ longitude at an altitude of $234.7 \mathrm{~m}$ above mean sea level and falls under Agroecological region No. 2 (M9E1) under Arid ecosystem (Hot Arid Eco-region), which is characterized by deep, sandy and coarse loamy, desert soils with low water holding capacity and hot and arid climate.

The soils of experimental field was loamy sand in texture having $\mathrm{pH}-8.2$, EC -0.22 dS $\mathrm{m}^{-1}$, available $\mathrm{N}-90.1 \mathrm{~kg} \mathrm{ha}^{-1}$, available $\mathrm{P}_{2} \mathrm{O}_{5}$ - $14.2 \mathrm{~kg} \mathrm{ha}^{-1}$, available $\mathrm{K}_{2} \mathrm{O}-160.4 \mathrm{~kg} \mathrm{ha}^{-1}$, avalable Zinc- $0.34 \mathrm{mg} \mathrm{kg}{ }^{-1}$, avalable iron$2.90 \mathrm{mg} \mathrm{kg}^{-1}$ and organic carbon- $0.15 \%$.

The field experiment on wheat in rabi seasons of 2009-10 and 2010-11 was laid out comprising 4 levels of phosphorus $(0,20,40$ and $\left.60 \mathrm{~kg} \mathrm{ha}^{-1}\right)$ and zinc $\left(0,3\right.$ and $\left.6 \mathrm{~kg} \mathrm{ha}^{-1}\right)$ in main plots and 3 levels of iron $(0,3$ and $6 \mathrm{~kg}$ $\left.\mathrm{ha}^{-1}\right)$ in sub plots. A total of 36 treatment combinations were tested in split plot design with three replications. The treatment details are follows: 


\section{(A) Main plot treatments}

\section{Phosphorus levels}

$\mathrm{P}_{0}=$ Control, $\mathrm{P}_{1}=20 \mathrm{Kg} \mathrm{ha}^{-1}, \mathrm{P}_{2}=40 \mathrm{Kg}$ ha- 1 and $\mathrm{P} 3=60 \mathrm{Kg} \mathrm{ha}^{-1}$

\section{Zinc levels}

$\mathrm{Zn}_{0}=$ Control, $\mathrm{Zn}_{1}=3 \mathrm{Kg} \mathrm{ha}^{-1}$ and $\mathrm{Zn}_{2}=6 \mathrm{Kg}$ ha $^{-1}$

\section{(B) Sub plot treatments}

\section{Iron levels}

$\mathrm{Fe}_{0}=$ Control, $\mathrm{Fe}_{1}=3 \mathrm{Kg} \mathrm{ha}^{-1}$ and $\mathrm{Fe}_{2}=6 \mathrm{Kg}$ $\mathrm{ha}^{-1}$

Nitrogen was applied @ $120 \mathrm{~kg} \mathrm{~N} \mathrm{ha}^{-1}$ was applied RDF. Half dose was applied as basal through urea after adjusting the quantity of $\mathrm{N}$ supplied by DAP. Remaining half dose of $\mathrm{N}$ was applied through broadcasting of urea in two equal split doses just after irrigation at 25 and 75 DAS. Potassium was applied @ 20 kg $\mathrm{K}_{2} \mathrm{O}$ ha $^{-1}$ was applied through muriate of potash before sowing. Phosphorus: Phosphorus was applied through DAP, zinc was applied through zinc sulphate and iron was applied through ferrous sulphate before sowing as per treatment. Seeds were treated with thiram (2 $\mathrm{g} \mathrm{kg}^{-1}$ seed) as prophylactic measures against seed borne diseases. The wheat variety 'Raj-3077' was sown by "kera" method at a depth of $5 \mathrm{~cm}$ in rows spaced at $22.5 \mathrm{~cm}$ apart on $25^{\text {th }}$ and $28^{\text {th }}$ November in the years 2009-10 and 2010-11, respectively using seed rate of $120 \mathrm{~kg} \mathrm{ha}^{-1}$.

The grain yield of each net plot was recorded in $\mathrm{kg} \mathrm{plot}{ }^{-1}$ after cleaning the threshed produce and was converted as $\mathrm{kg} \mathrm{ha}^{-1}$. Straw yield was obtained by subtracting the grain yield $\left(\mathrm{kg} \mathrm{ha}^{-1}\right)$ from biological yield $\left(\mathrm{kg} \mathrm{ha}^{-1}\right)$. The harvest index was calculated by using following formula and expressed as percentage (Singh and Stoskoof, 1971).

$$
\text { Harvest index }(\%)=\frac{\text { Economic yield }}{\text { Biological yield }} \times 100
$$

Fresh leaves collected at flowering stage from each plot were washed twice with water and once with distilled water. Treatment wise fresh leaf sample of $0.1 \mathrm{~g}$ was taken and ground in 80 per cent acetone, filtered from filter paper No. 42 and volume was made upto $25 \mathrm{ml}$. The resultant intensity of colour was measured in UV-VIS spectrophotometer 118 (systronics) at specific wave length $(645 \mathrm{~m} \mu$ and $663 \mathrm{m \mu}$ ) to estimate chlorophyll ' $\mathrm{a}$ ' and chlorophyll 'b' content (Arnon, 1949).

Chlorophyll 'a' content $\left(\mathrm{mg} \mathrm{g}^{-1}\right)=$

$12.7 \mathrm{~A}_{663}-2.69 \mathrm{~A}_{645}$

a x $1000 \times \mathrm{w}$

Chlorophyll 'b' content $\left(\mathrm{mg} \mathrm{g}^{-1}\right)=$

$22.9 \mathrm{~A}_{645}-4.68 \mathrm{~A}_{663}$

a x $1000 \times$ w

Where,

$\mathrm{a}=$ Length of light path in cell (usually $1 \mathrm{~cm}$ )

$\mathrm{w}=$ Fresh weight of leaf samples $(\mathrm{g})$

$\mathrm{v}=$ Volume of extract $(\mathrm{ml})$

Total chlorophyll content $\left(\mathrm{mg} \mathrm{g}^{-1}\right)=$ Chlorophyll 'a' + Chlorophyll 'b'

The protein content in grain was calculated by multiplying per cent nitrogen content with a factor of 6.25 (A.O.A.C., 1970). The sugar content was determined by the method described by AOAC (1970). The crude fiber content was calculated by using following formula and expressed in percentage as described by AOAC (1970). 
Crude fiber $(\%)=$

Weight of residue - Weight of ash

x 100

Amount of substance taken

\section{Results and Discussion}

\section{Effect of phosphorus}

Application of phosphorus at $40 \mathrm{~kg} \mathrm{P}_{2} \mathrm{O}_{5} \mathrm{ha}^{-1}$ significantly increased the grain yield, straw yield and biological yield over control during both year of experimentation and pooled analysis (Table 1). The significant increase in grain yield of wheat due to application of phosphorus up to $40 \mathrm{~kg} \mathrm{P}_{2} \mathrm{O}_{5} \mathrm{ha}^{-1}$ was largely a function of improved growth and the consequent increase in different yield attributes. The grain yield of wheat increased by $762 \mathrm{~kg} \mathrm{ha}^{-1}$ due to application of $40 \mathrm{~kg}$ $\mathrm{P}_{2} \mathrm{O}_{5}$ ha $^{-1}$ over control. Jain and Dahama (2006) and Jat et al., (2007) also recorded significant improvement in wheat grain yield with increase in phosphorus levels. The significant increase in straw yield due to application of phosphorus could be attributed to the increased vegetative growth as evident from dry matter production and CGR possibly as a result of the effective uptake and utilization of nutrients absorbed through its extensive root system developed under phosphorus fertilization (Rathi and Singh, 1976).

The biological yield is a function of grain and straw yields. Thus, significant increase in biological yield with the application of phosphorus could be ascribed to the increased grain and straw yields. The faster rate of improvement in grain yield as compared to straw yield to phosphorus fertilization led to significant improvement in biological yield thereby suggesting better source and sink relationship. These results are in conformity with those of Jat et al., (2007) and Sepat and Rai (2013).
Data perusal in Table 2 revealed that application of phosphorus @ $40 \mathrm{~kg} \mathrm{P}_{2} \mathrm{O}_{5} \mathrm{ha}^{-1}$ significantly increased the chlorophyll content of wheat at flowering stage during both the years of investigations and in pooled analysis. This may be attributed to increased $\mathrm{N}$ content in grain and its uptake by the crop and role of $\mathrm{P}$ in energy conservation and transformation. Higher nitrogen content in grain due to $\mathrm{P}$ fertilization resulted in higher crude protein content as nitrogen is an integral part of protein. Such increase in protein content is due to the reduction of nitrates to ammonia by the activities of complex enzymes resulting in production of more amino acids, which are main constituents of protein. These results are corroborates with the findings of Azad et al., (2010) and Pingoliya et al., (2015).

\section{Effect of zinc}

Application of zinc at $3 \mathrm{~kg} \mathrm{ha}^{-1}$ significantly increased the number of yield of wheat over control during both the years (Table 1). The increase in the yield due to zinc application may be attributed to the fact that the initial status of available zinc in the experimental soil was low. The increase in yield attributes may be due to increased supply of available zinc to plants by way of its addition to soil which resulted in proper growth and development. The increase in the yield attributes might be due to role of zinc in biosynthesis of indole acetic acid (IAA) and especially due to its role in initiation of primordia for reproductive parts and partitioning of photosynthates towards them, which resulted in better flowering and fruiting. The significant increase in straw yield due to zinc fertilization could be attributed to the increased plant growth and biomass production, possibly as a result of the uptake of nutrients. Similar results were reported by Singh et al., (2015) and Arshad et al., (2016). 
Table.1 Effect of phosphorus, zinc and iron on yield $\left(\mathrm{kg} \mathrm{ha}^{-1}\right)$ and harvest index of wheat

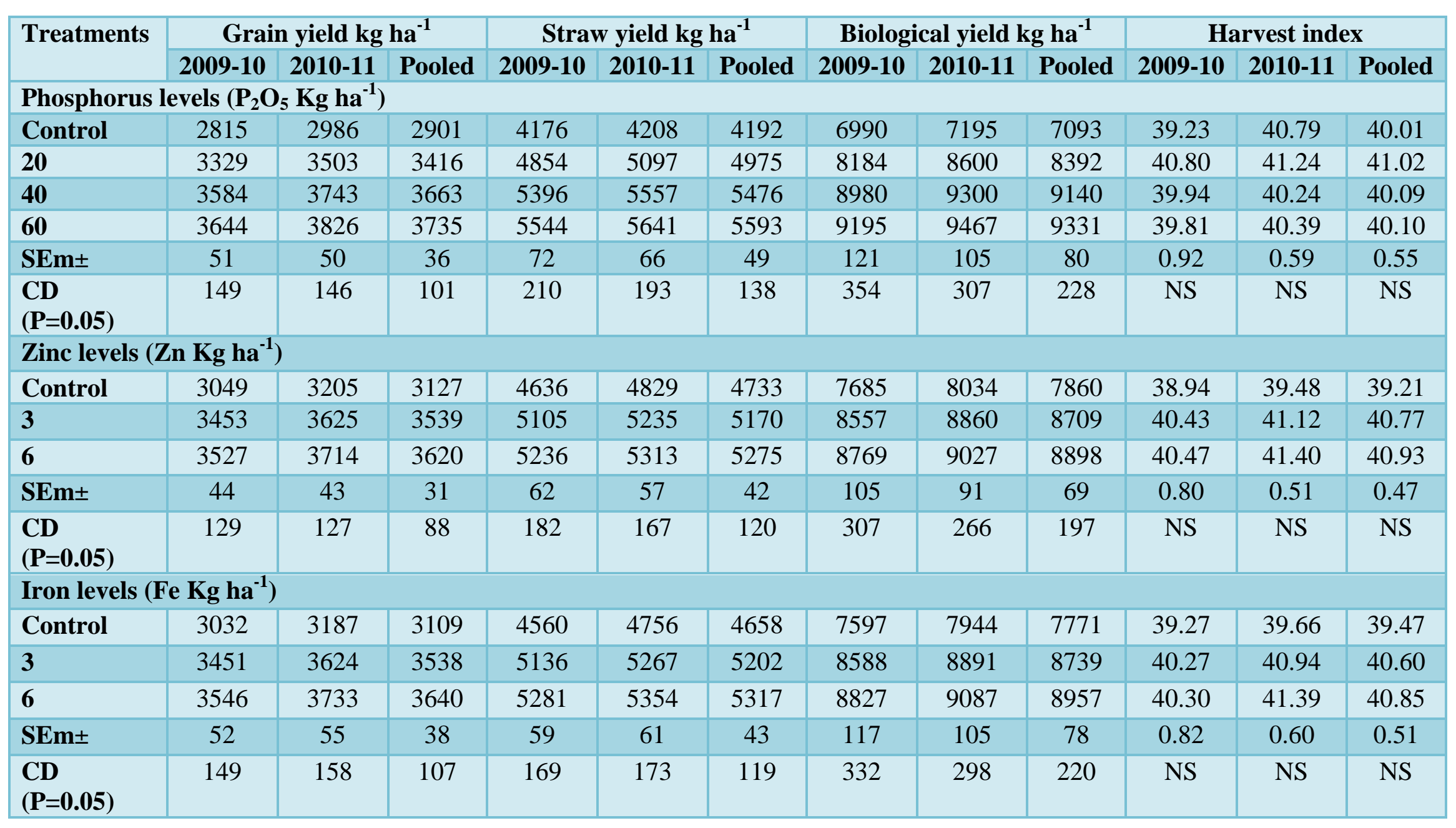


Table.2 Effect of phosphorus, zinc and iron on quality parameters of wheat

\begin{tabular}{|c|c|c|c|c|c|c|c|c|c|c|c|c|}
\hline \multirow[t]{2}{*}{ Treatments } & \multicolumn{3}{|c|}{$\begin{array}{l}\text { Chlorophyll content } \\
\text { (mg g } \text {-1 }^{-1} \text { of fresh leaves) }\end{array}$} & \multicolumn{3}{|c|}{$\begin{array}{l}\text { Protein content } \\
\text { of grain }(\%)\end{array}$} & \multicolumn{3}{|c|}{$\begin{array}{c}\text { Total sugar content } \\
\text { of grain }(\%)\end{array}$} & \multicolumn{3}{|c|}{$\begin{array}{c}\text { Crude fiber content } \\
\text { of grain }(\%)\end{array}$} \\
\hline & $\begin{array}{c}2009- \\
10\end{array}$ & $\begin{array}{c}2010- \\
11\end{array}$ & $\begin{array}{c}\text { Poole } \\
\text { d }\end{array}$ & 2009-10 & 2010-11 & $\begin{array}{c}\text { Poole } \\
\text { d }\end{array}$ & 2009-10 & $\begin{array}{c}2010- \\
11\end{array}$ & $\begin{array}{c}\text { Poole } \\
\text { d }\end{array}$ & 2009-10 & 2010-11 & Pooled \\
\hline \multicolumn{13}{|c|}{ Phosphorus levels $\left(\mathrm{P}_{2} \mathrm{O}_{5} \mathrm{Kg} \mathrm{ha}^{-1}\right)$} \\
\hline Control & 2.17 & 2.22 & 2.19 & 8.91 & 8.74 & 8.83 & 10.92 & 10.67 & 10.79 & 32.17 & 32.00 & 32.08 \\
\hline 20 & 2.61 & 2.66 & 2.64 & 9.67 & 9.82 & 9.74 & 10.94 & 11.05 & 11.00 & 31.60 & 31.66 & 31.63 \\
\hline 40 & 2.78 & 2.85 & 2.82 & 10.17 & 10.07 & 10.12 & 11.03 & 11.07 & 11.05 & 31.26 & 31.18 & 31.22 \\
\hline 60 & 2.87 & 2.92 & 2.90 & 10.29 & 10.28 & 10.29 & 11.07 & 11.31 & 11.19 & 31.17 & 30.71 & 30.94 \\
\hline SEm \pm & 0.06 & 0.05 & 0.04 & 0.10 & 0.14 & 0.09 & 0.30 & 0.21 & 0.18 & 0.40 & 0.45 & 0.30 \\
\hline $\mathrm{CD}(\mathrm{P}=\mathbf{0 . 0 5})$ & 0.18 & 0.14 & 0.11 & 0.28 & 0.42 & 0.25 & NS & NS & NS & NS & NS & NS \\
\hline \multicolumn{13}{|c|}{ Zinc levels ( $\mathrm{Zn} \mathrm{Kg} \mathrm{ha}{ }^{-1}$ ) } \\
\hline Control & 2.29 & 2.34 & 2.31 & 9.40 & 9.38 & 9.39 & 10.94 & 10.86 & 10.90 & 31.71 & 31.52 & 31.61 \\
\hline 3 & 2.72 & 2.79 & 2.76 & 9.87 & 9.83 & 9.85 & 10.97 & 11.06 & 11.01 & 31.63 & 31.46 & 31.54 \\
\hline 6 & 2.81 & 2.86 & 2.84 & 10.01 & 9.98 & 9.99 & 11.07 & 11.16 & 11.11 & 31.32 & 31.18 & 31.25 \\
\hline SEm \pm & 0.05 & 0.04 & 0.03 & 0.08 & 0.12 & 0.08 & 0.26 & 0.19 & 0.16 & 0.34 & 0.39 & 0.26 \\
\hline $\mathrm{CD}(\mathrm{P}=\mathbf{0 . 0 5})$ & 0.16 & 0.12 & 0.10 & 0.25 & 0.37 & 0.21 & NS & NS & NS & NS & NS & NS \\
\hline \multicolumn{13}{|c|}{ Iron levels (Fe Kg ha $\left.{ }^{-1}\right)$} \\
\hline Control & 2.31 & 2.37 & 2.34 & 9.42 & 9.40 & 9.41 & 10.77 & 10.74 & 10.75 & 31.63 & 31.44 & 31.53 \\
\hline 3 & 2.68 & 2.74 & 2.71 & 9.87 & 9.75 & 9.81 & 11.06 & 11.16 & 11.11 & 31.54 & 31.36 & 31.45 \\
\hline 6 & 2.84 & 2.89 & 2.86 & 9.99 & 10.04 & 10.01 & 11.15 & 11.19 & 11.17 & 31.49 & 31.36 & 31.42 \\
\hline SEm \pm & 0.04 & 0.03 & 0.02 & 0.12 & 0.13 & 0.09 & 0.22 & 0.15 & 0.13 & 0.28 & 0.28 & 0.20 \\
\hline $\mathrm{CD}(\mathrm{P}=0.05)$ & 0.11 & 0.09 & 0.07 & 0.35 & 0.36 & 0.25 & NS & NS & NS & NS & NS & NS \\
\hline
\end{tabular}


Application of zinc@ $3 \mathrm{~kg} \mathrm{ha}^{-1}$ significantly increased the chlorophyll content of wheat at flowering stage during both the years of study as well as on pooled basis. Experimental results also showed a significant increase in protein content in grain of wheat due to the application of zinc up to $3 \mathrm{~kg} \mathrm{ha}^{-1}$. Application of zinc in soil increased the availability of zinc in the rhizosphere. The role of zinc in increasing the metabolic and physiological activity of the plants is of great significance as it influences the activities of hydrogenase and carbonic anhydrase, stabilization of ribosomal fractions and synthesis of cytochrome (Tisdale et al., 1984). Similar results were also been reported by Shivay et al., (2014) and Paramesh et al., (2014).

\section{Effect of iron}

Application of $3 \mathrm{~kg} \mathrm{Fe} \mathrm{ha-1} \mathrm{significantly}$ increased the grain yield (Table 1) over control but it was found statistically at par with $3 \mathrm{~kg} \mathrm{Fe} \mathrm{ha}{ }^{-1}$. An increase in grain yield may be attributed to the significant increase in number of effective tiller per plant and number of grains per ear. Further, increase in grain yield due to iron application in the soil could possibly be due to the enhanced metabolites of carbohydrates and protein and their transport to the site of grain production. Since iron is a constituent of ferrodoxin and cytochromes, which involved in photosynthesis, the increase in iron supply could result in enhanced synthesis of carbohydrates. Similarly, significant increase in straw yield was recorded with the application of $3 \mathrm{~kg} \mathrm{Fe} \mathrm{ha}^{-1}$. This might be due to increased crop growth and development viz. dry matter accumulation and yield attributes of plants under better nutritional environment, under the application of iron. Significant increase in grain and straw yield due to iron application has also been reported by Habib (2009). The biological yield is a function of grain and straw yields. Thus, increase in biological yield with the application of iron could be ascribed to increase grain and straw yields. These results are in line conformity of findings of Gill and Walia (2014).

Application of iron@6 kg ha ${ }^{-1}$ significantly increased the chlorophyll content of wheat at flowering stage during both the years of study as well as on pooled basis. Application of $\mathrm{Fe}$ @ $6 \mathrm{~kg} \mathrm{ha}^{-1}$ significantly increased mean chlorophyll content by 22.20 per cent and 5.77 per cent over control and $3 \mathrm{~kg} \mathrm{Fe} \mathrm{ha}{ }^{-1}$, respectively. Data perusal in table 2 revealed that application of $\mathrm{Fe} @ 6 \mathrm{~kg}^{\mathrm{h}} \mathrm{ha}^{-1}$ significantly increased mean chlorophyll content by 22.20 per cent and 5.77 per cent over control and $3 \mathrm{~kg} \mathrm{Fe} \mathrm{ha}{ }^{-1}$, respectively. Whereas, application of iron @ $3 \mathrm{~kg} \mathrm{ha}^{-1}$ increased the protein content of wheat significantly during both the years of experimentation as well as in the pooled analysis. However, total sugar content of grain and crude fiber content of grain did not affected significantly during both the years of study as well as in the pooled analysis. Iron might have helped in greater nitrogen uptake by plant and translocation in various plant parts including grain. Since nitrogen is essential constitute of protein, increased nitrogen content led to higher protein content. These results corroborative with the findings of Pingoliya et al., (2015).

\section{References}

Anonymous 2014-15. Economic survey of India, Ministry of Finance (Economic Division) GOI, New Delhi.

AOAC 1970. Official methods of analysis. $9^{\text {th }}$ edition Association of Official Agricultural Chemists, Washington DC. Pp-119.

Arnon DI 1949. Copper enzyme in isolated chloroplast polyphenoxidase in Beta vulgaris. Plant Physiology, 24: 1-15. 
Arshad M, Adnan M, Ahmed S, Khan AK, Ali I, Ali M, Ali A, Khan A, Kamal MA and Gul F 2016. Integrated Effect of Phosphorus and Zinc on Wheat Crop. American-Eurasian Journal of Agriculture \& Environmental Science, 16 (3): 455-459.

Azad VB, Bali BS and Saha AAS 2010. Effect of phosphorus levels and biofertilizers on yield, P-uptake and economics of wheat (Triticum aestivum). Environment and Ecology, 28: (1B): 534-537.

Gill JS and Walia SS 2014. Effect of foliar application of iron, zinc and manganese on direct seeded aromatic rice (Oryza sativa). Indian Journal of Agronomy, 59 (1): 80-85.

Habib M 2009. Effect of foliar application of Zn and $\mathrm{Fe}$ on wheat yield and quality. African Journal of Biotechnology, 8 (24): 6795-6798.

Jain NK and Dahama AK 2006. Direct and residual effects of phosphorus and zinc fertilization on productivity of wheat (Triticum aestivum) - pearl millet (Pennisetum glaucum) cropping system. Indian journal of Agronomy, 51: 165169.

Jat BL, Shaktawat MS and Jat AS 2007. Effects of phosphorus levels alone or in combination with phosphate-solubilizing bacteria (Pseudomonas striata) and farmyard manure on growth, yield and nutrient uptake of wheat (Triticum aestivum). Journal of Agriculture and Social Sciences, 32: 78-82

Paramesh V, Dhar S, Vyas AK and Dass, A 2014. Studies on impact of phosphoenriched compost, chemical fertilizer and method of zinc application on yield, uptake and quality of maize (Zea mays). Indian Journal of Agronomy, 59 (4): 613-618.

\section{How to cite this article:}

Ram Chandar Jat, Yogesh Sharma, R.K. Jakhar and Sharma, R.K. 2018. Effect of Phosphorus, Zinc and Iron on Yield and Quality of Wheat in Western Rajasthan, India. Int.J.Curr.Microbiol.App.Sci. 7(03): 2055-2062. doi: https://doi.org/10.20546/ijcmas.2018.703.241
Pingoliya KK, Mathur AK, Dotaniya ML and Dotaniya CK 2015. Impact of phosphorus and iron on protein and chlorophyll content in chickpea (Cicer arietinum L.). Legume Research, 38 (4): 558-560.

Rathi SS and Singh D 1976. Effect of nitrogen and phosphate fertilization on the growth and yield of gram. Indian Journal of Agronomy, 21(3): 305-306.

Sakal R and Singh AP 2001. Micronutrient in relation to response and quality of crop. Journal of Agricultural Chemistry, 14: 45.

Sanyal SK and De Datta SK 1991. Chemistry of phosphorus transformation in soil. Advances in Soil Science, 16: 1-120.

Sepat S and Rai RK 2013. Effect of phosphorus levels and sources on productivity, nutrient uptake and soil fertility of maize (Zea mays)-wheat (Triticum aestivum) cropping system. Indian Journal of Agronomy, 58 (3): 292-297.

Shivay YS, Prasad R and Pal M 2014. Effect of variety and zinc application on yield, profitability, protein content and zinc and nitrogen uptake by chickpea (Cicer arietinum). Indian Journal of Agronomy, 59 (2): 317-322.

Singh ID and Stoskoof YC 1971. Harvest Index in cereals. Agronomy Journal, 63: 224226.

Singh V, Javed A, Seema, Kumar A and Chauhan TM 2015. Productivity, nutrient uptake and economics of wheat (Triticum aestivum) under potassium and zinc nutrition. Indian Journal of Agronomy, 60 (3): 426-430.

Tisdale SL, Nelson WL and Beaten JD 1984 Zinc in Soil Fertility and Fertilizers. Fourth edition, Macmillan Publishing Company, New York, pp- 382-391. 